\section{The Relationship between Depression and Anxiety and Heart Failure Patients' Adherence to Self-Care Recommendations}

\author{
JAAFAR $\mathrm{MH}^{1}$, VILLIERS-TUTHILL A², MCGEE $\mathrm{H}^{3}$, MORGAN K${ }^{1}$ \\ ${ }^{1}$ Perdana University-Royal College of Surgeons in Ireland, Perdana University, 43400 Seri \\ Kembangan, Selangor, Malaysia \\ 2Endocrine Unit, St. Columcilles Hospital, Loughlinstown, Co. Dublin, D18 E3665, \\ Ireland \\ ${ }^{3}$ Royal College of Surgeons in Ireland, Dublin, Ireland, 123 St Stephen's Green, Dublin, \\ D02 YN77, Ireland
}

\begin{abstract}
ABSTRAK
Kegagalan jantung untuk berfungsi dengan baik adalah sesuatu keadaan perubatan yang dapat melemahkan fizikal dan psikologi. Walaupun kemurungan adalah salah satu tanda terhadap kemerosotan jantung untuk berfungsi dengan baik, hanya sedikit kajian yang menumpukan kepada tabiat kebiasaan dan rutin harian. Kajian ini bertujuan untuk mengkaji hubungan antara kemurungan dan kebimbangan terhadap pesakit yang menghidapi kegagalan jantung bersesuaian dengan tingkah laku penjagaan diri pesakit. Temubual telah diadakan dengan 161 pesakit di klinik pesakit luar hospital. Kemurungan dan kebimbangan telah dinilai dengan menggunakan skala Hospital Anxiety and Depression Scale (HADS). Tingkah laku penjagaan diri dinilai dengan menggunakan European Heart Failure Self-Care Behaviour Scale (EHFSCBS). Kemurungan klinikal berkemungkinan ditunjukkan pada 18\%, dan kebimbangan klinikal berkemungkinan pada 16\% pesakit. Kesesuaian tingkah laku penjagaan kendiri berbeza dengan banyaknya dan mencatatkan peratusan paling tinggi untuk mengambil ubat seperti yang ditetapkan (93.1\%), dan bertenang jika tidak boleh bernafas (75.1\%) dan peratusan lebih rendah untuk pemeriksaan berat badan sendiri (13.6\%), senaman tetap (33.6\%) dan menghadkan pengambilan cecair (38.5\%). Tiada hubungan yang penting ditemui di antara keseluruhan pematuhan penjagaan diri dan kebimbangan atau kemurungan yang dilaporkan. Walau bagaimanapun, hubung kait yang signifikan dengan kemurungan telah ditemui untuk lima daripada 12 item penjagaan diri, dan juga dengan kebimbangan untuk dua daripadanya. Keputusan kami menunjukkan bahawa kesejahteraan mental pada pesakit dengan kegagalan jantung memainkan
\end{abstract}

Address for correspondence and reprint requests: Karen Morgan. Perdana University Royal College of Surgeons in Ireland School of Medicine, Perdana University, Serdang, Malaysia. Tel: +603-8941 8646 Email: karenmorgan@perdanauniversity.edu.my 
peranan penting dalam keupayaan pesakit untuk mematuhi penjagaan diri.

Kata kunci: Kegagalan jantung, kemurungan, kepatuhan, kerisauan, penjagaan diri

\begin{abstract}
Heart failure is a physically debilitating and psychologically distressing chronic condition. Although depressive disorder is a strong predictor of short-term deterioration of heart failure symptoms and mortality, only few studies have focused on habit and daily routines. The present study aimed to investigate the relationship between depression and anxiety and heart failure patients' self-care behaviour. Interviews were completed with 161 patients at hospital outpatient clinics in Belfast and Dublin. Depression and anxiety were assessed using the Hospital Anxiety and Depression Scale (HADS). Self-care behaviour was assessed using the European Heart Failure Self-Care Behaviour Scale (EHFSCBS). 'Probable' clinical depression was indicated in $18 \%$, and 'probable' caseness of anxiety disorder in $16 \%$ of patients. Self-care behaviour adherence varied considerably across behaviours and was higher for taking medication as prescribed (93.1\%), and taking it easy if breathless (75.1\%) and lower for daily self-weighing (13.6\%), regular exercise $(33.6 \%)$ and limiting fluid intake (38.5\%). No significant relationship was found between overall reported self-care adherence and anxiety or depression. However, significant association with depression were found for five of the 12 self-care items, and also with anxiety for two of these. Our results demonstrated that mental well-being in patients with heart failure plays a significant role in the patients' ability to adhere to self-care regimens.
\end{abstract}

Keywords: adherence, anxiety, depression, heart failure, self-care

\section{INTRODUCTION}

Prevalence and incidence of heart failure (HF) are high and numbers continue to rise placing significant burden on the health care system. The British Society for Heart Failure reported $73-81 \%$ admissions to hospitals in England and Wales were due to HF (Donkor et al. 2016). In Ireland, there are 90,000 patients with HF (Moran et al. 2014). Results from a Rotterdam study revealed that lifetime risk for HF was $33 \%$ for men and $29 \%$ for women at the age of 55 (Bleumink et al. 2004). Heart failure is a physically debilitating and psychologically distressing chronic condition. The impact on patient quality of life (QoL) is substantial, with heart failure patients experiencing some of the worst physical and social problems reported by chronically ill patients (Moraska et al. 2013).

Higher rates of depression are well documented in HF outpatients and inpatients (Moudgil \& Haddad 
2013; Rutledge et al. 2006; Sedlar et al. 2017) and are generally higher for heart failure than other cardiac groups (Rustad et al. 2013). HF and depression have profound effects on functional status and QoL which can lead to poor outcomes, morbidity and mortality (Mbakwem et al. 2016). While many studies have focused on depression, the effects of anxiety in HF patients have been under-researched (Pelle et al. 2008).

Self-care is an important aspect of treatment of heart failure (Lainscak et al. 2011) and in the prevention of hospital readmission. However, there are significant challenges for patients due to its multifaceted nature and complexity. Non-adherence to treatment continues to be a problem in heart failure patients. A meta-analysis of 25 studies examining the effects of depression and anxiety on adherence found that patients with depression were more likely to be non-adherent to medical treatment recommendations than those without depression. Anxiety, however, had an unclear relationship with adherence (DiMatteo et al. 2000). The objective of this study was to investigate the relationship between depression and anxiety and heart failure patients' self-care behaviour.

\section{MATERIALS AND METHODS}

A total of 161 patients (response rate: 83\%) were recruited from Cardiology Clinics at the outpatient departments (OPDs) of three large urban hospitals one in Belfast and two in Dublin.

Patients were included in the study if they were diagnosed with heart failure with an ejection fraction of $<40 \%$ as confirmed by the medical team, were not admitted to the hospital within a month prior to inclusion, and were stable on oral HF medication during that month. The ejection fraction of $<40 \%$ was chosen based on the National Institute for Health and Care Excellence (NICE) guidelines (NICE 2018). Patients were excluded if they could not speak English, were less than 18 years of age, had life-threatening co-morbidities, or had a history of acute psychiatric condition and severe cognitive impairment as determined by The Abbreviated Mental Test. Ethical approval to conduct the study was granted by the relevant Hospital Ethics (Medical Research) Committees and the Northern Ireland Clinical Governance committee. The investigation was in line with the principles outlined in the Declaration of Helsinki.

Patients were interviewed within two weeks of hospital discharge or during their first follow-up hospital outpatient appointment. Length of time since diagnosis and classification of heart failure were collected using the New York Heart Association classification (NYHA) questionnaire (a 4 point classification scale from 1 (mild) to 4 (severe) (Maron et al. 2006). The interview included questionnaires to assess depression, anxiety and selfcare behaviours. The Abbreviated Mental Test was used to screen for cognitive impairment. It has 10 questions with each question correctly answered scoring one point. The questions test for short-term memory, recall, orientation, language and calculation. We excluded patients with 
scores of $<6$ points (out of a total of 10) which suggests "probable cognitive impairment" (Hodkinson 1972).

Depression and anxiety were assessed using the Hospital Anxiety and Depression Scale (HADS) (Zigmond \& Snaith 1983). Compared to other assessment instruments, the HADS is a valid, simple and widely used screening tool which is often used to identify specific mental disorders (Ceccarini et al. 2014). It was used to screen for the presence of possible and probable anxiety and depression in non-psychiatric patients. It has 14 items with two subscales: anxiety subscale (HADS-A) and depression subscale (HADS-D). Anxiety and depression items are rated on a 4-point scale and are scored separately. For each subscale, a score of seven and below was classified as 'normal'; a score of 8-10 was classified as 'borderline abnormal (borderline case' ' and a score of 11 and above was classified as 'abnormal (case)' of either depression or anxiety. Patients who screened with high anxiety and depression were evaluated by their physician if judged to be clinically indicated, but as standard practice, we recommended the patients to be monitored for two weeks.

Self-care behaviour was evaluated using the European Heart Failure Self-Care Behaviour Scale (EHFSCBS). This scale has 12 items. It is a selfadministered questionnaire that concerns the self-care behaviour of heart failure patients. Every item takes the form of a statement e.g. 'I limit the amount of fluids', 'I eat a low salt diet' and 'I take my medication as prescribed'. Every statement has a 5-point scale that ranges from 1 (' completely agree') to 5 ('I don't agree at all'). Total scale scores range from 12 to 60 with lower score indicates better self-care. However, for a better understanding, we reversed the score so that higher scores now indicate higher levels of self-care. The EHFSCBS is a reliable, valid, and practical scale to measure the self-reported self-care of heart failure patients (Jaarsma et al. 2003).

Data was analysed using SPSS Version 21. Descriptive statistics were used to characterize this sample. Normality of continuous variables was assessed by Kolmogorov-Smirnov test. Baseline differences in sample population were calculated using Chisquare tests for categorical variables and independent samples t-tests and ANOVA for continuous variables. To examine the strength of relations, Pearson's correlations were calculated. $\mathrm{P}<0.05$ was regarded as significant.

\section{RESULTS}

The characteristics of participants are displayed in Table 1. The mean age of the participants was 69.2 years (SD 9.1), and $81.4 \%$ were male. The majority, $80.7 \%$, were married, while $13 \%$ lived alone. More than three quarters $(77 \%)$ had at least second level education (high school). Average time since diagnosis of having heart failure was $4.86 \pm 3.4$ years. There were $29.8 \%(n=48)$ in NYHA class $1,47.8 \%$ $(n=77)$ in class 2, 17.4\% $(n=28)$ in class 3 and $5 \%(n=8)$ in class 4 . There was positive correlation between the 
Table 1: Characteristics of participants

\begin{tabular}{lcc}
\hline & Variable & Percentage \\
\hline Age, mean (SD) & Male & $69.2(9.1)$ \\
Gender & Female & 81.4 \\
& Married & 18.6 \\
Marital Status & Widowed & 81 \\
& Never Married / Single & 12 \\
Living Arrangements & Separated / Divorced & 3 \\
& Living with Others & 4 \\
Education & Living Alone & 13 \\
& Primary & 17 \\
Time Since Diagnosis of HF, years (mean (SD)) & Secondary & 77 \\
& Tertiary & 6 \\
& Class 1 & $29.8 \%(\mathrm{n}=48)$
\end{tabular}

length of time, since diagnosis and NYHA classification, with more severe heart failure associated with being diagnosed for a longer time $(r=0.217$; $\mathrm{p}=0.006$ ). More severe heart failure was also associated with being older $(r=0.285, p<0.001)$.

\section{Depression and Anxiety}

HADS-D scores indicated the case of clinical depression happened in $18 \%$ of patients, while $16 \%$ had HADS-A scores indicating anxiety disorder. Both depression $(r=0.206, p=0.004)$ and anxiety ( $r=0.136, p=0.042)$ were significantly correlated with NYHA class. Depression was also significantly correlated with marital status $(r=0.315$, $p=<0.001)$, and age $(r=0.176, p=0.013)$.

\section{Self-care Behaviour}

Adherence was computed as percentage of patients scoring one or two on the five-point scale. Greater adherence was reported for taking medication as prescribed (93.1\%), and taking it easy if breathless (75.1\%). Low adherence was reported for daily self-weighing $(13.6 \%)$, regular exercise $(33.6 \%)$ and limiting fluid intake (38.5\%). Adherence for other behaviours varied from $39 \%$ to $62 \%$. The mean cumulative self-care score was 29.9 (SD 9.48) within a possible range of 12 to 60 .

\section{Relationships between Self-care and Depression and Anxiety}

There were no significant associations 
Table 2: Significant correlations with Self-Care behaviour items

\begin{tabular}{lcc}
\hline \multicolumn{1}{c}{ Self-Care Behaviour } & $\begin{array}{c}\text { HADS-D } \\
\text { Pearson Correlation } \\
\text { (2-tailed Sig.) }\end{array}$ & $\begin{array}{c}\text { HADS-A } \\
\text { Pearson Correlation } \\
\text { (2-tailed Sig.) }\end{array}$ \\
\hline I weigh myself every day & $0.232^{* *}(0.003)$ & $0.005(0.949)$ \\
If I get short of breath I take it easy & $-0.361^{* *}(<0.001)$ & $-0.082(0.301)$ \\
I take a rest during the day & $-0.353^{* *}(<0.001)$ & $-0.213^{* *}(0.007)$ \\
I get a flu injection every year & $-0.163^{*}(0.039)$ & $-0.101(0.202)$ \\
I exercise regularly & $0.168^{*}(0.034)$ & $0.294^{* *}(<0.001)$ \\
\hline$*$ Correlation is significant at the 0.01 level (2-tailed). ${ }^{* *}$ Correlation is significant at the 0.05 level (2-tailed). \\
\hline
\end{tabular}

at univariate level between depression or anxiety and overall self-care score. However, HADS-D scores were significantly associated with five of the 12 individual self-care items, and anxiety was also significantly associated with two of these (Table 2). Both HADS-D and HADS-A were positively correlated with taking a rest during the day and negatively correlated with exercising regularly.

\section{DISCUSSION}

With regard to depression, a study contributed to the body of evidence (Sedlar et al. 2017). The current study figures of $18 \%$ cases of depression, are slightly less than that reported in the previous meta-analysis (Rutledge et al. 2006) which showed that significant depression was present in $21.5 \%$ of heart failure patients. The current result was also lower than another recent meta-analysis (Ren et al. 2014). In terms of anxiety cases, this study presented $16 \%$ cases which is also lower than a previous study (Haworth et al. 2005). This could be due to the health education and awareness that may have contributed to the low depression and anxiety. Besides that, well-trained staff, adequate technology, and conducive environment might have influenced the results ( $\mathrm{Ho}$ et al. 2007). Studies have suggested that depression among patients with $\mathrm{HF}$ is associated with worst outcomes including mortality, diminished quality of life, and an increased rate of cardiacrelated morbidity (Hare et al. 2014; Mbakwem et al. 2016). Rutledge and colleagues (Rutledge et al. 2006) also found that NYHA classification was positively correlated with anxiety and depression scores, a finding that was replicated in this study.

The complexity of treatment regimens presents an arduous responsibility for the patient and unsurprisingly levels of adherence to treatment regimens are often reported to be poor (Maeda et al. 2013). A previous study has reported that non-adherence can be a precursor to events which can lead to $64 \%$ of hospitalisations among the heart failure population (De Geest et al. 2003). Reasons given for non-adherence include interference with socialisation, lack of knowledge, lack of food choices and perceived low palatability of low sodium foods, 
inadequate social support, anxiety, and depression (Bennett et al. 2005; Bentley et al. 2005).

Reported self-care behaviour differed significantly by activity. More than $90 \%$ of patients indicated that they took their medication as prescribed. Similar high rates of adherence to medication regimens have been reported in other studies (Evangelista et al. 2003; Ni et al. 1999). Symptom reporting levels were also lower than other reported behaviours $(62.1 \%)$, which is congruent with research that has noted delays in helpseeking among heart failure patients (Evangelista et al. 2000).

Weight-based diuretic adjustment and weight monitoring are often recommended as part of heart failure self-care in order to prevent heart failure exacerbations and reduce volume overload (Lainscak et al. 2011). In this study, adherence to daily weighing by patients was the lowest of all self-care behaviours measured at only $13.6 \%$. In contrast, other studies have reported rates of daily weight monitoring between 25\% and 40\% (Artinian et al. 2002; Holst et al. 2007; Ni et al. 1999). Non-adherence to self-weighing recommendations is associated with knowledge, beliefs regarding the benefit of recommended behaviours and not having a scale (van der Wal et al. 2006; Wright et al. 2003). Besides focused interventions, such as coaching, teaching back, or diseasemanagement programs that should be effective to encourage weight monitoring, a strong component that can improve the accuracy of patients' belief should also be included (Jones et al. 2012).

Recognition and treatment of depression is an essential component of heart failure care. A previous study reported that depression among heart failure patients was associated with a large increase in acute healthcare utilization and mortality (Moraska et al. 2013). However, some researchers have raised concerns that depression is not routinely addressed in this group (Koenig 2007). Guidelines such as the UK National Institute for Health and Clinical Excellence (NICE) 2003 guidelines state that depression should be taken into account in all heart failure patients. Nevertheless, the implementation of such guidelines in practice is complex (Tully et al. 2014) and evidence exists that depression treatments are under-prescribed for this group (Jacob et al. 2003).

The present study found a significant association between anxiety and adherence to two aspects of self-care behaviour. The association between adherence and anxiety was less clear than that with depression. This is probably due to because anxiety may range from panic to obsessivecompulsive behaviour which may in fact, as suggested by the results of this study, increase adherence. Furthermore, depression tends to cooccur with higher levels of anxiety, making it difficult to draw conclusions in relation to anxiety alone (Dekker et al. 2014).

The overall level of heart failure severity in this study makes it a very appropriate group on which to base considerations for interventions. A potential limitation of this study is 
that the percentage of women in the sample was small (less than 20\%) making it difficult to generalize the results. The limitations of assessing self-care behaviour by self-report or in an interview were discussed predominantly in relation to medication adherence. As discussed previously, medication adherence for heart failure is very complex. Nonadherence should not be assumed to be deliberate; patients may be unaware that they are being non-adherent to the details of a prescribed regimen. Hence, a discrepancy may arise between selfreported and monitored adherence.

\section{CONCLUSION}

Depression is significantly associated with five of the 12 individual selfcare items, and anxiety was also significantly associated with two of these. Treatment regimens are complex and there are many barriers to adherence. Patients often report high levels of psychological distress, poor quality of life and difficulties adhering to treatment regimens. This study adds to the body of evidence supporting the role of mental well-being in patients' ability to adhere to self-care regimens and as such highlights the importance of addressing depression and anxiety in this growing patient population.

\section{REFERENCES}

Artinian, N.T., Magnan, M., Sloan, M., Lange, M.P. 2002. Self-care behaviors among patients with heart failure. Heart Lung 31(3): 161-72.

Bennett, S.J., Lane, K.A., Welch, J., Perkins, S.M., Brater, D.C., Murray, M.D. 2005. Medication and dietary compliance beliefs in heart failure. West J Nurs Res 27(8): 977-93.
Bentley, B., De Jong, M.J., Moser, D.K., Peden, A.R. 2005. Factors related to nonadherence to low sodium diet recommendations in heart failure patients. Eur J Cardiovasc Nurs 4(4): 331-6.

Bleumink, G.S., Knetsch, A.M., Sturkenboom, M.C., Straus, S.M., Hofman, A., Deckers, J.W., Witteman, J.C., Stricker, B.H. 2004. Quantifying the heart failure epidemic: prevalence, incidence rate, lifetime risk and prognosis of heart failure The Rotterdam Study. Eur Heart J 25(18): 1614-9.

Ceccarini, M., Manzoni, G.M., Castelnuovo, G. 2014. Assessing depression in cardiac patients: what measures should be considered? Depress Res Treat 2014: 148256.

De Geest, S., Scheurweghs, L., Reynders, I., Pelemans, W., Droogne, W., Van Cleemput, J., Leventhal, M., Vanhaecke, J. 2003. Differences in psychosocial and behavioral profiles between heart failure patients admitted to cardiology and geriatric wards. Eur J Heart Fail 5(4): 557-67.

Dekker, R.L., Lennie, T.A., Doering, L.V., Chung, M.L., Wu, J.R., Moser, D.K. 2014. Coexisting anxiety and depressive symptoms in patients with heart failure. Eur J Cardiovasc Nurs 13(2): 168-76.

DiMatteo, M.R., Lepper, H.S., Croghan, T.W. 2000. Depression is a risk factor for noncompliance with medical treatment: meta-analysis of the effects of anxiety and depression on patient adherence. Arch Intern Med 160(14): 2101-7.

Donkor, A., McDonagh, T., Hardman, S. 2016. National Heart Failure Audit Annual Report. Retrieved from London.

Evangelista, L., Doering, L.V., Dracup, K., Westlake, C., Hamilton, M., Fonarow, G.C. 2003. Compliance behaviors of elderly patients with advanced heart failure. J Cardiovasc Nurs 18(3): 197-206.

Evangelista, L.S., Dracup, K., Doering, L.V. 2000. Treatment-seeking delays in heart failure patients. J Heart Lung Tranplant 19(10): 932-8.

Hare, D.L., Toukhsati, S.R., Johansson, P., Jaarsma, T. 2014. Depression and cardiovascular disease: a clinical review. Eur Heart J 35(21): 1365-72.

Haworth, J.E., Moniz-Cook, E., Clark, A.L., Wang, M., Waddington, R., Cleland, J.G. 2005. Prevalence and predictors of anxiety and depression in a sample of chronic heart failure patients with left ventricular systolic dysfunction. Eur J Heart Fail 7(5): 803-8.

Ho, S.E., Syed Zulkifli, S.Z., Raja Lexshimi, R.G., Hamidah, H., Santhna, L., Teoh, K.H., Razali, O., Hanida, M. 2007. Anxiety and depression among patients before and after percutaneous coronary intervention $(\mathrm{PCl})$ at National Heart Institute (NHI). Med \& Health 2(1): 26-33.

Hodkinson, H.M. 1972. Evaluation of a mental test score for assessment of mental impairment in the elderly. Age Ageing 1(4): 233-8. 
Holst, M., Willenheimer, R., Martensson, J., Lindholm, M., Stromberg, A. 2007. Telephone follow-up of self-care behaviour after a single session education of patients with heart failure in primary health care. Eur J Cardiovasc Nurs 6(2): 153-9.

Jaarsma, T., Stromberg, A., Martensson, J., Dracup, K. 2003. Development and testing of the European Heart Failure Self-Care Behaviour Scale. Eur J Heart Fail 5(3): 363-70.

Jacob, S., Sebastian, J.C., Abraham, G. 2003. Depression and congestive heart failure: are antidepressants underutilized? Eur J Heart Fail 5(3): 399-400.

Jones, C.D., Holmes, G.M., DeWalt, D.A., Erman, B., Broucksou, K., Hawk, V., Cene, C., Wu, J.R., Pignone, M. 2012. Is Adherence to weight monitoring or weight-based diuretic self-adjustment associated with fewer heart failure-related Emergency Department visits or hospitalizations? J Card Fail 18(7): 576-84.

Koenig, H.G. 2007. Recognition of depression in medical patients with heart failure. Psychosomatics 48(4): 338-47.

Lainscak, M., Blue, L., Clark, A.L., Dahlström, U., Dickstein, K., Ekman, I., McDonagh, T., McMurray, J.J., Ryder, M., Stewart, S., Strömberg, A., Jaarsma, T. 2011. Self-care management of heart failure: practical recommendations from the Patient Care Committee of the Heart Failure Association of the European Society of Cardiology. Eur J Heart Fail 13(2): 115-26.

Maeda, U., Shen, B.J., Schwarz, E.R., Farrell, K.A., Mallon, S. 2013. Self-Efficacy mediates the associations of social support and depression with treatment adherence in heart failure patients. Int J Behav Med 20(1): 88-96.

Maron, B. J., Towbin, J.A., Thiene, G., Antzelevitch, C., Corrado, D., Arnett, D., Moss, A.J., Seidman, C.E., Young, J.B. 2006. Contemporary definitions and classification of the cardiomyopathies: an American Heart Association Scientific statement from the council on clinical cardiology, heart failure and transplantation committee; quality of care and outcomes research and functional genomics and translational biology interdisciplinary working groups; and Council on Epidemiology and Prevention. Circulation 113(14): 1807-16.

Mbakwem, A., Aina, F., Amadi, C. 2016. Expert opinion-depression in patients with heart failure: is enough being done? Card Fail Rev 2(2): $110-2$.

Moran, D., Buckley, A., Daly, K., Meaney, B., Curtin, R., O'Neill, J.O., Colwell, N., Mahon, N., Murphy, N., O'Hanlon, R., Daly, C., Mc Adam, B., Mc Donald, K., Maher, V. 2014. Heart rate awareness in patients with chronic stable heart failure. A multi-center observational study. Int J
Cardio/ 177(2): 380-4.

Moraska, A.R., Chamberlain, A.M., Shah, N.D., Vickers, K.S., Rummans, T.A., Dunlay, S.M., Spertus, J.A., Weston, S.A., McNallan, S.M., Redfield, M.M., Roger, V.L. 2013. Depression, healthcare utilization, and death in heart failure: a community study. Circ Heart Fail 6(3): 387-94.

Moudgil, R., Haddad, H. 2013. Depression in heart failure. Curr Opin Cardiol 28(2): 249-58.

Ni, H., Nauman, D., Burgess, D., Wise, K., Crispell, K., Hershberger, R.E. 1999. Factors influencing knowledge of and adherence to self-care among patients with heart failure. Arch Intern Med 159(14): 1613-9.

NICE. 2018. Chronic heart failure in adults. Royal College of Physicians: National Institute for Health and Care Excellence.

Pelle, A.J., Gidron, Y.Y., Szabó, B.M., Denollet, J. 2008. Psychological predictors of prognosis in chronic heart failure. J Card Fail 14(4): 341-50.

Ren, Y., Yang, H., Browning, C., Thomas, S., Liu, M. 2014. Prevalence of depression in coronary heart disease in China: a systematic review and meta-analysis. Chin Med J 127(16): 2991-8.

Rustad, J.K., Stern, T.A., Hebert, K.A., Musselman, D.L. 2013. Diagnosis and treatment of depression in patients with congestive heart failure: a review of the literature. Prim Care Companion CNS Disord 15(4).

Rutledge, T., Reis, V.A., Linke, S.E., Greenberg, B.H., Mills, P.J. 2006. Depression in heart failure a meta-analytic review of prevalence, intervention effects, and associations with clinical outcomes. J Am Coll Cardiol 48(8): 1527-37.

Sedlar, N., Lainscak, M., Martensson, J., Strömberg, A., Jaarsma, T., Farkas, J. 2017. Factors related to self-care behaviours in heart failure: A systematic review of European Heart Failure Self-Care Behaviour Scale studies. Eur J Cardiovasc Nurs 16(4): 272-82.

Tully, P.J., Wittert, G., Selkow, T., Baumeister, H. 2014. The real world mental health needs of heart failure patients are not reflected by the depression randomized controlled trial evidence. PloS one 9(1): e85928.

van der Wal, M.H.L., Jaarsma, T., Moser, D. K., Veeger, N.J.G.M., van Gilst, W.H., van Veldhuisen, D.J. 2006. Compliance in heart failure patients: the importance of knowledge and beliefs. Eur Heart J 27(4): 434-40.

Wright, S.P., Walsha, H., Ingleya, K.M., Muncastera, S.A., Gamblea, G.D., Pearlb, A., Whalleya, G. A., Sharpea, N., Doughtya, R.N. 2003. Uptake of self-management strategies in a heart failure management programme. Eur J Heart Fail 5 371-80.

Zigmond, A.S., Snaith, R.P. 1983. The hospital anxiety and depression scale. Acta Psychiatr 
Scand 67(6): 361-70.

Received: 1 Feb 2019

Accepted: 29 Jul 2019 